\title{
Review of Benjamin Balak's McCloskey's rhetoric: discourse ethics in economics. New York: Routledge, 2006, 142 pp.
}

\author{
DANIEL VARGAS GÓMEZ \\ EIPE, Erasmus University Rotterdam
}

Benjamin Balak presents the reader with a concise yet densely philosophical narrative in which rhetorical analysis in economics, as it follows from Deirdre McCloskey, is explained, expanded, criticized, and related to ethics. The endeavor is Herculean, and so is the task of the reader who decides to follow him through a series of intricate paths, which go from the Vienna circle to deconstruction, and from Plato to Feyerabend. Throughout the journey, the reader is prompted to realize the importance-for economic science-of McCloskey's criticism, and the potential that rhetorical analysis has for future work throughout the field. ${ }^{1}$

Balak commences his work by introducing, without any warning to the reader, a series of philosophical authors and the 'method' to be followed. Within a few pages the reader is told that deconstruction, drawing from Derrida and Culler specifically, will be used profusely as a way to shed light on McCloskey's criticism of philosophy and methodology in economics. To the uninitiated in methodological and epistemological matters (economists for the most part, I presume) this can, surely, sound frightening, for they are certainly entering unknown territory. The relation between economics and these philosophical ideas may seem anything but straightforward. However, Balak makes a constant effort to relate both disciplines, and to stay in constant conversation with the economist just as much as with his philosophically inclined readers.

He begins with a delineation of McCloskey's criticism, promising to focus mainly on McCloskey's (1994) Knowledge and persuasion in economics. Her criticism, the reader is told, can be understood as having three main targets: 1) social engineering in economics: where successful

\footnotetext{
${ }^{1}$ McCloskey's criticism and development of 'the rhetoric of economics' began with her wildly acclaimed eponymous paper in the Journal of Economic Literature (1983). In 1985, she published a book under the same title, collecting together and expanding her rhetorical project.
} 
prediction is taken as a sign of true knowledge and thus of the power to change outcomes through policies; 2) blackboard economics: empirically empty and thus always risking irrelevance; and 3) the confusion between statistical and (real) economic significance: statistics alone cannot answer the question of "how big is big?" or the need for economists to focus on welfare questions that spring from statistical discussion, like: how many people will be worse or better off?

Balak's exposition of McCloskey's critique is clear and illuminating. This section of the book (chapter 2) is a great introduction for those who are not familiar with McCloskey's writings, or have had difficulties understanding her ideas in a coherent and methodical way.

After a serious exploration of McCloskey's criticism the reader is embarked in a difficult philosophical conversation (chapter 3): the exchange between Uskali Mäki and Deirdre McCloskey on the rhetoric of economics project. $^{2}$ There is a clarifying exposition of arguments and misunderstandings, but, particularly, a critical reading of Mäki's "dry" analytical reconstruction, as well as of McCloskey's lack of involvement and even paternalism in her reproach. In short, Mäki is portrayed as following the Platonic gesture that has characterized western philosophy throughout history: foundationalism as the basis for any methodological discussion. McCloskey's idea of rhetoric, the reader must bear in mind, does not claim to belong to methodological discussions in a conventional way. She is not interested in positing a set of epistemological rules, but, on the contrary, to denounce the strictness and sterility of traditional methodology. In turn, "the rhetoric" is proposed as a coherence theory of truth, without any axiomatic core to be found (Balak 2006, 54-58). Mäki's criticism fails to engage in a profound reading of McCloskey's anti-foundationalist position as a result of his poor understanding of the postmodern-like ideas that populate her writing. The analytical-continental split comes frequently to mind throughout the exchange and may lead the reader, from time to time, to see both views as simply incommensurable.

Surprisingly enough, there is a point that Balak concedes to Mäki, with respect to the moral constraint that seems to support McCloskey's idea of a "rhetorically conscious" community. The fact that "the rhetoric" is a bricolage that rests on persuasion, argument, and

\footnotetext{
2 Balak focuses mainly on Mäki's "Diagnosing McCloskey" (1995) and McCloskey's reply: "Modern epistemology against analytic philosophy: a reply to Mäki" (1995). Both articles can be found in the same issue of the Journal of Economic Literature.
} 
conversation (Balak 2006, 51), and not a proper methodology begs the question of normativity: for how is the scientific effort to be directed if the task of choosing between all theories that are built into a coherent system is a rhetorically persuasive one? Mäki, says Balak, wants to solve the matter by constraining the set of beliefs that form a coherence theory of truth (McCloskey's) based on their plausibility. Plausibility would thus become the criteria of selection to him.

Balak argues in favor of McCloskey's reply though. He eagerly wants to show that Mäki seems to condition the answer to come, hence avoiding the deeper elements of the disagreement (mainly over epistemological issues). Briefly, Balak argues that McCloskey does not adhere to a "theory of truth T" (universal, complete, and so on), because she's trying to avoid metaphysics, while Mäki is trying to "push" his. She's not making the naïve claim that there is no truth, but that all truths are socially constructed (even those that Mäki would favor).

McCloskey belongs within a 'postmodern' view of philosophy and one cannot engage with her properly unless one understands where she's coming from. In keeping with his original intention, in chapter 4 Balak begins a "Proof" of this claim, as a way to inundate the dry land left after the Mäki-McCloskey exchange. He uses Foucault in order to stress that knowledge is not exterior or alien to the social context from which it emerges. They are, in actuality, different sides of the same coin. The importance of language is also stressed and a hurried rendition of the Searle-Derrida debate is presented. The notions of context, iterability, and a criticism of speech-act theory's view of intentionality are all main points in this chapter. All of them pose a difficult reading, filled with questions. The argument here is quite dense, I should add, and will ask an effort on behalf of the reader, which may take him to engage with the original texts. ${ }^{3}$

Chapter 5 turns to a clarification of McCloskey's take on ethics. Ethics is important, Balak tells us, because it relates to McCloskey's attempt to delimit the conversation, thus creating an ethics of conversation (pp. 105-106). Concretely, ethics plays an important role in economic science. Having an understanding of the ethical commitments involved in the application of economic theory, via economic policy, is part of what the economist should be able to talk about.

\footnotetext{
${ }^{3}$ Derrida's essay, which originated the debate, together with a summary of Searle's response to it, and Derrida's response to Searle's response can be found in Derrida's Limited Inc (1988).
} 
Balak ends his take on McCloskey's ethical perspective by talking about an understanding of ethical rules as following an evolutionary process, which includes historical as well as biological determination. The discussion goes from Veblen to Vernon Smith, and back to Nietzsche. This last part is more for the reader interested in an understanding of ethics including historical as well as biological aspects, but it is not a necessary consequence following from McCloskey's ideas.

The book ends (in McCloskey's fashion) with the peroratio: an analysis of the ethical commitments behind knowledge production, where McCloskey's take on ethics becomes useful. The ethical standpoint of McCloskey, says Balak, comes precisely as a consequence of her epistemological perspective: given that truth is contextual, coming always from a perspective, it is ethical to root for pluralism and tolerance within the scientific conversation. The rhetorical analysis of economics leads in fact, he concludes, to a new pragmatism (p. 121).

All in all, the book serves the purpose of effectively introducing the reader into the ideas underlying McCloskey's rhetorical project. Balak's analysis is well supported with quotations and references. The analysis of the Mäki-McCloskey debate is interesting as well for various reasons, including its illustration of the difficulties that emerge in actual conversations between scientists, which the author addresses carefully. Those with only a casual interest in McCloskey's work on rhetoric may find parts of this book too demanding, but those with a more systematic interest will appreciate its depth and sophistication.

\section{REFERENCES}

Balak, Benjamin. 2006. McCloskey's rhetoric: discourse ethics in economics. New York: Routledge [INEM series].

Derrida, Jacques. 1988. Limited Inc. Evanston (IL): Northwestern University Press.

Mäki, Uskali. 1995. Diagnosing McCloskey. Journal of Economic Literature, 33 (3): 13001318.

McCloskey, Deirdre N. 1983. The rhetoric of economics. Journal of Economic Literature, 21 (2): 481-517.

McCloskey, Deirdre N. 1985. The rhetoric of economics. Madison: University of Wisconsin Press.

McCloskey, Deirdre N. 1994. Knowledge and persuasion in economics. Cambridge: Cambridge University Press.

McCloskey, Deirdre N. 1995. Modern epistemology against analytic philosophy: a reply to Mäki. Journal of Economic Literature, 33 (3): 1319-1323. 
Daniel Vargas Gómez is currently a research master student at the Erasmus Institute for Philosophy and Economics, Erasmus University Rotterdam. His MA thesis "Producing postmodern economics: an interpretation of Deirdre McCloskey's rhetoric of economics" focuses on the constructive articulation of elements of rhetorical analysis, hermeneutics, and deconstruction, within the construction of a contemporary economic conversation.

Contact e-mail: <312662dv@eur.nl> 